\title{
UNDERSTANDING THE U.S. EXPORT BOOM
}

\author{
Andrew B. Bernard \\ J. Bradford Jensen
}

Working Paper 6438 
NBER WORKING PAPER SERIES

UNDERSTANDING THE U.S. EXPORT BOOM

Andrew B. Bernard

J. Bradford Jensen

Working Paper 6438

http://www.nber.org/papers/w6438

\author{
NATIONAL BUREAU OF ECONOMIC RESEARCH \\ 1050 Massachusetts Avenue \\ Cambridge, MA 02138 \\ March 1998
}

Bernard' s research was supported by the Industrial Performance Center at MIT. Jensen's research was conducted while he was at the Center for Economic Studies at the Bureau of the Census. All errors are ours. Any opinions expressed are those of the authors and not those of the Bureau of the Census or the National Bureau of Economic Research.

(C) 1998 by Andrew B. Bernard and J. Bradford Jensen. All rights reserved. Short sections of text, not to exceed two paragraphs, may be quoted without explicit permission provided that full credit, including () notice, is given to the source. 
Understanding the U.S. Export Boom

Andrew B. Bernard and J. Bradford Jensen

NBER Working Paper No. 6438

March 1998

JEL Nos. F10, F14

\section{ABSTRACT}

U.S. exports grew at a rate of $8.2 \%$ per year from 1987-1994, far faster than the economy as a whole or even the manufacturing sector. This paper examines the source of this export boom and argues that the boom itself has been less remarkable for the rate of growth of exports than for the striking increase in export intensity. This increase in export intensity has occurred both in the aggregate and for individual plants across a wide range of industries. Competing explanations for the rise in exports are tested with a comprehensive plant level data set. Changes in exchange rates and rises in foreign income are the dominant sources for the export increase, while productivity increases in U.S. plants play a relatively small role. The results suggest that slower growth rates of U.S. trading partners and an appreciation of the dollar will have strong negative effects on the growth rate of U.S. manufacturing exports.

Andrew B. Bernard

Yale School of Management

135 Prospect Street

New Haven, CT 06511

and NBER

andrew.bernard@yale.edu
J. Bradford Jensen

H. John Heinz III School of Public Policy and Management

Carnegie Mellon University

Pittsburgh, PA 15213 


\title{
Understanding the U.S. Export Boom
}

\author{
Andrew B. Bernard*
}

Yale School of Management

National Bureau of Economic Research

\section{J. Bradford Jensen}

\section{H. John Heinz School of Public Policy \\ Carnegie Mellon University}

January, 1998 хз.0

U.S. exports grew at a rate of $8.2 \%$ per year from 1987-1994, far faster than the economy as a whole or even the manufacturing sector. This paper examines the source of this export boom and argues that the boom itself has been less remarkable for the rate of growth of exports than for the striking increase in export intensity. This increase in export intensity has occured both in the aggregate and for individual plants across a wide range of industries. Competing explanations for the rise in exports are tested with a comprehensive plant level data set. Changes in exchange rates and rises in foreign income are the dominant sources for the export increase, while productivity increases in U.S. plants play a relatively small role. The results suggest that slower growth rates of U.S. trading partners and an appreciation of the dollar will have strong negative effects on the growth rate of U.S. manufacturing exports.

KEY WORDS: hysteresis, export supply elasticity, productivity, exchange rate JEL Classification: F10, F14

*135 Prospect St., New Haven CT 06511, tel: (203) 432-5965, fax: (203) 432-6974, email: andrew.bernard@yale.edu Bernard's research was supported by the Industrial Performance Center at MIT. Jensen's research was conducted while he was at the Center for Economic Studies at the Bureau of the Census. Opinions expressed in this paper are those of the authors and do not necessarily reflect official positions of the Bureau of the Census. All errors are ours. 


\section{Introduction}

Exports have been booming. No matter how one slices the data, the results are the same. After seven years of stagnation, the value of total U.S. exports took off after 1987, increasing at an average annual rate of $8.2 \%$ from $\$ 402$ billion to $\$ 715$ billion by $1994 .^{1}$ Growth rates for exports of goods $(9.1 \%)$, and especially those of durable goods $(11.0 \%)$, were even more robust. By contrast, annual growth in real GDP and industrial production averaged only $2.2 \%$ and $2.8 \%$ respectively. (See Figure 1) This resurgence in exports has led to a huge sigh of relief from observers of U.S. manufacturing. Largely gone are the worries and woes of the 1980s that the U.S. had lost its edge. Instead, optimism abounds about the competitiveness of the manufacturing sector. $^{2}$

In this paper, we question whether such a buoyant feeling is justified from the export numbers alone. While it is true that the increase in exports has occurred in every manufacturing sector and in almost every state, we argue that the extraordinary growth in exports is largely a return to trend and a recovery from the overvaluation of the U.S. dollar during the early 1980s. Even though exports merely returned to long run trend levels during the boom, the export intensity of U.S. output increased at an unprecedented rate, both for the manufacturing sector as a whole and for individual plants and firms. It is this increase of export intensity which represents the real export boom of the late 1980s and 1990s.

The widespread nature of the export increase is remarkable. The export boom touched all industries in the manufacturing sector and nearly every state. Every sector saw its exports rise by at least $50 \%$ from the 1987 level, while nine industries more than doubled their exports. There was more heterogeneity across states although every one saw a rise in exports. At the firm level, more firms exported in 1992 than in 1987 and the exporters increased their share of shipments going abroad.

There are as many explanations for the rebirth of the export sector as there are new exporters, however, two competing stories dominate the debate. The first attributes the increase in exports to a general renewal of U.S. manufacturing, and in particular to increase in productivity at manufactur-

\footnotetext{
${ }^{1}$ Economic Report of the President (1996). All values are given in $\$ 1992$.

${ }^{2}$ Of course, merchandise imports continued to exceed exports, although they rose at a slower rate of $5.6 \%$.
} 
ing establishments. The argument is that manufacturers undertook large restructuring efforts during the mid and late 1980s which improved productivity and thus enabled them to compete in world markets. We consider this hypothesis in terms of shifts of the cost curve for individual producers and ask whether such movements are strongly correlated with increased exports.

The second, and not necessarily mutually exclusive, hypothesis about the export boom focuses on the role of foreign factors, especially exchange rates. Proponents argue that the dollar depreciation of the mid 1980s actually drove the export increase albeit with a lengthy delay. The delay in response to the large exchange rate movements is attributed to the presence of sunk costs of entry into exporting.

The difference in implications of the two hypotheses for the future performance of U.S. exports are quite stark. If exchange rate movements were driving the export increase, then future export growth is likely to moderate. ${ }^{3}$ The inevitable conclusion is that the export boom was a temporary phenomenon. However, if renewed U.S. manufacturing productivity was the dominant source of fast export growth rates, then continued rapid growth depends on further productivity improvements and may well continue into the future.

To evaluate these competing hypotheses, we first examine the contributions of new plants and new exporters to the export increases. While there has been an important increase in the numbers of plants exporting, by far the biggest increase in exports has come from existing exporters. We decompose the aggregate increase into two components, one due to increasing export intensity by individual exporters, and the other due to increasing shipments at relatively export intensive plants. Both effects are occurring during the boom but the increase in export intensity is the dominant effect.

As a more formal test, we regress changes in exports and export intensity at the plant level on exchange rate, foreign demand and plant productivity measures. The results suggest that all three variables are playing a role in the export increase but that the productivity effect is relatively small. The depreciation of the dollar coupled with increases in foreign income account for almost $90 \%$ of the export increase in the aggregate.

The paper proceeds as follows: the next section details the scope of the

${ }^{3} \mathrm{~A}$ large appreciation of the dollar and slow foreign income growth would exacerbate the slowdown in export growth. 
export boom across industries and regions. Section 3 put the recent increases in exports in a longer historical context. The contributions of new plants and new exporters are discussed in Section 4 as well as the role of increasing export intensity at the plant level. Section 5 contains the tests of the competing hypotheses using plant level data for all plants and continuing exporters. Section 6 presents the relative contributions of exchange rates, foreign income and plant productivity to aggregate export increases. Section 7 concludes.

\section{Depth and Breadth of the Boom}

The recent period of export growth truly was the rising tide that lifted all boats. ${ }^{4}$ Every two-digit manufacturing industry had faster export growth than output growth. ${ }^{5}$ Every state showed growth in exports and only six had slower export growth than manufacturing growth. ${ }^{6}$ In addition, the proportion of manufacturing plants and firms that exported rose substantially and exporters shipped a higher fraction of their output abroad.

The export boom was felt in every industry in the manufacturing sector. Table 1 reports shipments and direct export values for 1987 and 1992 for each two-digit manufacturing sector. ${ }^{7}$ Export growth was substantially higher than shipments growth in every industry, even textiles, furniture, and apparel were able to more than double their value of exports. Perhaps not

${ }^{4}$ All our plant and firm level figures come from the Census Bureau's Census of Manufactures (CM) for 1987 and 1992. The CM surveys U.S. manufacturing establishments and collects information on production and non-production employment, production hours, salaries and wages, shipments, value-added, capital measures, ownership structure, and direct exports. The coverage of exports is less than $100 \%$. For details on this issue see Bernard and Jensen (1995). Due to limitations with the 1992 CM, we exclude all plants with fewer than 20 employees. Inclusion of these plants will not substantially change any of our conclusions as these plants are less likely to be exporters and account for a small fraction of U.S. manufacturing output and exports.

${ }^{5}$ Two-digit manufacturing industries are food, tobacco, textiles, apparel, wood, furniture, paper, printing, chemicals, petroleum, rubber, leather, stone, primary metals, fabricated metals, machinery, electronics, transportation, instruments, and miscellaneous manufacturing.

${ }^{6}$ The six, Minnesota, Missouri, Vermont, West Virginia, Wyoming, and South Dakota, accounted for only $6 \%$ of direct exports in 1987.

${ }^{7}$ These industry numbers represent direct exports reported by establishments in the Censuses of Manufactures. Actual export volume is higher, as indirect exports are not included. 
surprisingly, traditionally strong export sectors continued to dominate the aggregate numbers. The top five exporting industries, transportation, machinery, chemicals, electronics and instruments, accounted for $77 \%$ of total exports in 1987 and $72 \%$ in 1992 and two-thirds of the total increase. Transportation and machinery remained the top two manufacturing export sectors and increased their exports at more than twice the rate of the increase in shipments. The breadth of the export boom gives clues as to its sources. Every industry participated, including those that were expanding rapidly such as chemicals and electronics as well as declining industries such as leather and stone. This broad scope of the increase suggests that the sources of the boom are likely to be factors that affect all sectors.

The shift into exporting across industries can also be seen in Table 2 which reports the share of exporting firms by industry. Nationally the fraction of exporting plants rose from $21 \%$ to $30 \%$ in just 5 years. The most exportintensive industries judged by participation rates were instruments, tobacco, chemicals, electronic equipment, and machinery which all had more than $33 \%$ of plants involved in the direct export market in 1987. In 1992 participation rates in these sectors had risen to more than $43 \%$. However, striking changes also occurred in less likely areas. Primary metals saw an increase in exporting plants from $28 \%$ to $38 \%$ while the fraction of furniture exporters rose from $10 \%$ to $24 \%$.

The export boom did not just touch all industries, it reached into almost every area of the country, as shown in Table 3. Except for the Northeast where every state had both sluggish or negative growth in shipments and only modest increases in exports, other regions showed substantial export growth. Traditional export states such as California, Ohio, and especially Washington all saw large rises in export volume. However, Idaho, Nebraska, and Georgia were among the fastest growing export states.

The export boom of the late 1980s and early 1990s swept across industries, regions, and firms. Participation rates in the international market soared in all sectors and a large fraction of the growth in manufacturing shipments can be associated with the increase in exports. 


\section{A Long Run Perspective}

There is little question that the increase in exporting after 1987 was felt in every industry and every region of the country. However, the perception that the U.S. has entered a new regime of increasing openness and export growth is due in large part to the contrast between the early 1980's and more recent years. For the seven years from 1980 to 1987, the real value of U.S. exports grew at a rate of only $2.8 \%$ per year, ${ }^{8}$ while for the seven years from 1987-1994, as noted earlier, export growth averaged $8.0 \%$ per year. However, in comparison to earlier periods, the export growth of recent years is less extraordinary.

Figure 2 shows the log-level of U.S. exports in billions of $\$ 1992$ for the period 1959-1994. Export growth, represented by the change in the loglevels, averaged $6.6 \%$ for the entire period from 1959-1994, or only $1.2 \%$ lower than the rate for 1987-1994. More remarkably, a log-linear trend fitted to value of exports from 1959-1973 predicts the level of exports in 1994 to within $2 \%$ of the actual value. There are three distinct phases in U.S. export performance over the 35 year period: sustained rapid growth from 1959-1980, low or negative growth rates until 1987 and above average growth since 1987. It appears, at least from visual inspection of the data, that the increases in recent years have merely returned the level of exports to where it would have been in the absence of the dollar appreciation of the early 1980's.

If the export boom has not been an unusual event in terms of growth rates, the question remains why there is the widespread perception that the U.S. has gone through an unprecedented episode of increasing exports. The answer lies in the varying performance of the domestic economy over the same period. Figure 3 shows the export to GDP ratio for the U.S. from 1959-1994.

Again the picture reveals several distinct episodes. Both exports and GDP were growing rapidly during the 1960s and early 1970s, with exports increasing slightly faster, thus raising the export/GDP ratio from 0.032 in 1959 to 0.047 in 1972. Export growth rates rose somewhat in the rest of the 1970s while overall GDP growth rates slipped. By 1980 the export/GDP ratio had climbed to 0.071 where it stagnated during the export doldrums of the next seven years. The largest period of change for the export/GDP ratio

${ }^{8}$ Almost half of the growth for the earlier period occurred between 1986 and 1987. 
has been in the 1987-1994 period where it has climbed to an unprecedented 0.108 due to renewed rapid export growth and only modest GDP growth.

This large increase in the share of GDP accounted by exports (and a commensurate rise in the import-GDP ratio) has been the single most important change during the so-called export boom. While the level of exports is not unusually high, at least according to the standards of long run trend growth rates, the export/GDP ratio is at an all-time high, and likely to increase further, unless there is a revival in domestic shipment growth. In the sections that follow we consider competing hypotheses about the source of the increase in exports and also the increase in export intensity.

\section{Decomposing Export Growth}

In attempting to understand the growth of exports in recent years, we start with a simple accounting exercise, decomposing the growth in aggregate exports into the contributions from existing plants, new plants, and new exporters. Total direct exports reported by plants in the Census of Manufactures increased by $\$ 80.9$ bn from 1987 to 1992 (see Table 4). Of that total increase, $87 \%$ came from plants that existed in both years, while $13 \%$ came from the net change due to additions from new plants (29\%) less the decline from plants that failed in the intervening years $(-16 \%)$. For plants that existed in both years, exporters in both periods accounted for $\$ 49.7 \mathrm{bn}$, or $61 \%$, of the aggregate increase in exports. New exporters added $\$ 30.8 \mathrm{bn}$ in exports while there was a $\$ 9.7 \mathrm{bn}$ decline from plants exiting from the export market.

As noted earlier, the percentage of plants exporting increased from $21.5 \%$ to $31.2 \%$ in just five years (see Figure 4 ). While these new exporters played an important role in export growth over the period, contributing almost $40 \%$ of the total growth, the bulk of the increase came from increased export intensity at existing exporters. The scope of the increase in exports can be seen clearly in Figure 5 which shows the shift in the distribution of exporting establishments to the right. Among plants that export, greater numbers now export a larger fraction of their output, although the vast majority of exporters still ship a relatively small fraction of their output abroad. However, the export boom not only saw the numbers of exporters increase in every part of the distribution, but the increase was largest for plants that shipped a large portion of their output abroad. 
Masked by these numbers is the extent to which individual plants increased their export intensity or merely increased their overall shipments, including exports. For any given plant, exports might increase because the plant became more export intensive or because shipments increased, even thought the exports/shipments ratio remained constant. We decompose the increase in aggregate exports into two components,

$$
\Delta E=\underbrace{\sum_{i} \Delta S_{i} \overline{\left(E_{i} / S_{i}\right)}}_{\text {Growth Effect }}+\underbrace{\sum_{i} \Delta\left(E_{i} / S_{i}\right) \overline{S_{i}}}_{\text {Intensity Effect }}
$$

for $i=1, \ldots, I$ plants where $\Delta E$ is the aggregate change in exports, $\Delta S_{i}$ is the change in the level of shipments at plant $i, \Delta\left(E_{i} / S_{i}\right)$ is the change in the share of exports in shipments at plant $i . \overline{\left(E_{i} / S_{i}\right)}$ and $\overline{S_{i}}$ are time averages of $\left(E_{i} / S_{i}\right)$ and $S_{i}$. The total increase in exports can stem from relatively large increases in shipments at export-intensive plants, the growth effect, or from increases in export intensity, the intensity effect, or some combination of the two.

Table 5 reports the two measures for new exporters (starters), former exporters (stoppers) and plants that export in both years. For all plants taken together as well as for exporters in both periods, increases in export intensity were the largest contributor to aggregate export growth. However, increased shipments at export-intensive firms accounted for more than $37 \%$ of the export increase in the aggregate and for more than $42 \%$ of the increase for continuing exporters. The decomposition confirms the earlier findings that the dominant characteristic of the export boom was an increase in export intensity, both at the plant level as well as for the economy as a whole.

\section{Sources of the Boom}

The two main competing (but not mutually exclusive) explanations for the resurgence in U.S. exports are the real devaluation of the dollar from 19851987 and increased productivity at U.S. manufacturers. In this section we test these hypotheses using the plant level data from the Censuses of Manufactures for 1987 and 1992. We first discuss the differences between plants that export in the beginning of the period and those that are out of the export market initially and then present results for all plants taken together and exporters in both periods. 
The theoretical debate over the slow response of U.S. exports to the decline in the dollar during the mid-1980s has focussed on the existence of entry or sunk costs for potential exporters. As argued by Dixit (1989), Baldwin and Krugman (1989) and Krugman(1989), if firms face one-time costs upon beginning to export, there will be a range of inaction in the face of seemingly favorable exchange rate shocks. Bernard and Jensen (1997) use plant-level data to test for the existence of such entry costs in the U.S. and find strong evidence in favor of sunk costs of exporting. A plant that is not exporting today is $40 \%$ less likely to be in the export market next year than a comparable plant that is an exporter today. Those results also show a positive but small increase in the probability that a firm will export when faced with favorable exchange rate movements. As a result of the presence of sunk costs, we would expect that the export-exchange rate elasticity for all firms taken together would be substantially smaller than that of today's exporters.

Firms already participating in the export market account for the bulk of the increase in exports. Starting from the assumption that individual exporters face downward sloping foreign demand for their products and that domestic supply shifts are uncorrelated with changes in demand, we can represent the quantity of exports from any individual plant as

$$
E_{i}=F(D, S)
$$

where $D$ is a vector of demand shifters including, but not limited to, increases in foreign income and movements in the exchange rate. $S$ includes variables that shift the export supply, or cost, curve of the plant and can be represented by measures of plant level productivity. The simplest exposition of these two effects can be seen in Figure 6. Changes in exports from the plant can result from shifts in demand, as seen in the upper diagram, or shifts in supply, as represented in the lower box. If the plant faces very elastic demand for its product, as is likely in an industry with multiple producers, then small outwards shifts in the supply (from $\mathrm{S}^{1}$ to $\mathrm{S}^{2}$ ) may result in large increase in exports. Similarly if plants are producing in a flat, or even downward sloping, segment of their average cost curve then small shifts in foreign demand may induce a large supply response.

Normally, identification of supply and demand shocks is difficult and requires the use of appropriate instruments. In the case of exports at the plant level, however, the problem is substantially mitigated by the separation of 
factor markets, which are typically local, and demand which is generated abroad. Especially for an economy of the size of the U.S., it seems reasonable to assume that favorable changes in exchange rates and foreign income do not shift down the cost curves of individual domestic firms. ${ }^{9}$ Similarly, foreign demand is very unlikely to be affected by domestic supply shocks.

A greater problem lies in the construction of suitable measures of changes in foreign demand. The use of aggregate exchange rate and foreign GDP measures is infeasible as they do not vary in interesting ways across plants, or even industries. Instead to capture changes in foreign demand, we construct industry specific (4 digit SIC) exchange rate and foreign income measures given as follows

$$
\begin{aligned}
& X R_{j}=\sum_{m}\left(\frac{E_{j m}}{E_{j}}\right) \cdot X R_{m} \\
& Y_{j}=\sum_{m}\left(\frac{E_{j m}}{E_{j}}\right) \cdot Y_{m}
\end{aligned}
$$

where $m$ indexes countries, $E_{j m}$ is the value of exports from industry $j$ to country $m, E_{j}$ is the total value of exports from industry $j$, and $X R_{m}$ and $Y_{m}$ are the real exchange rate index and PPP-converted GDP of country $m$ respectively. These industry variables are weighted exchange rate and income measures, where the weights represent the share of exports from the industry to the country. ${ }^{10}$

Our preferred measure of shifts in the supply curve is a measure of labor productivity at the establishment. We use valued-added per worker, $V A / N$, as the labor productivity measure and use plant level changes from 1987-1992 to represent shifts of the cost curve. A potential problem with such a variable arises if changes in export quantities or export intensity are sources of, rather than responses to, shifts in productivity. While we recognize this problem, recent work has found no positive feedback from exporting to productivity (see Bernard and Jensen 1998).

${ }^{9}$ In fact, if some fraction of intermediate inputs are imported then a depreciation will raise unit costs.

${ }^{10}$ We have industry export information for the top 25 US export destinations and use the average shares from 1984-1992 as the weights. The nominal country exchange rates are adjusted using GDP deflators and converted into indices where 1987=100. Foreign incomes are converted into constant dollars using 1990 PPP exchange rates. 
To measure the growth in exports, we use two indicators. First we consider the percentage increase in exports as given by the percentage change in exports ( $\Delta$ lnexports). However this measure is defined only for plants that export in both years, so we also use a measure of export growth at the plant given by

$$
\frac{E_{t}-E_{t-1}}{0.5\left(E_{t}+E_{t-1}\right)}
$$

This measure is defined for all plants whether or not they export in a given year and ranges from $[-2,2] .^{11}$

Finally, since the increase in export intensity at the plant level is the major contributor to the aggregate increase in exports, we also consider the determinants of the change in export intensity at the plant, given by the increase in the exports to shipments ratio,

$$
\Delta\left(\frac{E_{i}}{S_{i}}\right)
$$

We regress each of these measures of the increase from 1987 to 1992 in export activity at the plant on percentage changes in the exchange rate, productivity, and foreign income measures described above,

$$
\Delta \text { Exports Measure }_{i j}=\beta_{1} \Delta X R_{j}+\beta_{2} \Delta \ln Y_{j}+\beta_{3} \Delta \ln \left(\frac{V A}{N}\right)_{i j}+\epsilon_{i j} .(5)
$$

The expected coefficients are negative for $\beta_{1}$ (a positive change in $X R_{j}$ indicates an appreciation of the U.S. currency), positive for $\beta_{2}$, and positive for $\beta_{3}$.

Table 6 contains regression results for the change in exports and the exports-shipments ratio for all plants taken together over the period 19871992. By necessity, we include only plants for which we have observations in both years, eliminating all plants that fail during the interval and those that enter after 1987. The resulting sample accounts for $89 \%$ of exports in both years.

For the export growth measure, we find significant coefficients on all three variables with the expected sign in each case. ${ }^{12}$ Both the exchange rate and

\footnotetext{
${ }^{11}$ Davis, Haltiwanger, and Schuh (1996) use this measure in their work on gross job creation and destruction.

${ }^{12}$ For the panel of all plants, we do not report the regression for $\Delta$ lnexports since by construction it includes only plants that export in both periods. See Table 7.
} 
foreign income quasi-elasticities are quite large, point estimates of -0.92 and 0.75 respectively, indicating that firms respond strongly to foreign demand shocks. ${ }^{13}$ As noted above, this is to be expected if establishment supply and demand curves are relatively flat. The export response to productivity improvements is significant and positive, but substantially smaller in magnitude with a point estimate of 0.033 .

Using the change in export intensity as the dependent variable, we find again that the foreign variables have significant coefficients with the expected sign and of substantial magnitude. A $10 \%$ depreciation of the industry exchange rate is associated with a $0.4 \%$ increase in export intensity at the average plant. Foreign income changes have even larger effects on the composition of output. Productivity improvements at the plant have no significant effects on the composition of output across foreign and domestic shipments, the sign of the coefficient is negative but not significant.

Since we would eventually like to be able to describe the aggregate export response to exchange rate movements, we rerun our specifications for the sample of plants that export in both 1987 and 1992. These continuing exporters account for over $70 \%$ of total exports in both years and the bulk of the increase in aggregate exports. Since this group of plants has already incurred any sunk costs in the decision to enter the foreign market, our estimates of the export responses should be greater than those for the sample of all plants taken together and should give us a "cleaner" estimate of the true export supply elasticities.

In Table 7, we report regression results for all three export measures and find, as expected, a much stronger supply response in this sample of plants. Both exchange rate and output supply elasticities are substantially greater than one. Even the productivity elasticity is more than four times larger for this group of plants, suggesting that both supply and demand curves are quite flat once firms have entered the export market.

For these exporting plants, the share of goods shipped abroad responds much more strongly to changes in exchange rates and foreign income. A 10\% deprecation shifts $1.5 \%$ of output towards foreign sales. However, productivity increases are now negatively related to export intensity suggesting the shifts of the supply curve increase domestic shipments faster than foreign

\footnotetext{
${ }^{13}$ The use of this measure for export growth, i.e. $\left[E_{t}-E_{t-1}\right] /\left[0.5\left(E_{t}+E_{t-1}\right)\right]$, underestimates the true elasticities since it is bounded between -2 and 2 by construction.
} 
shipments.

These results indicate that, to some degree, both changes in foreign demand, working through exchange rates and income, and changes in productivity played a role in the increase in exports from 1987 to 1992. However, to the extent that the export boom was associated primarily with increasing export intensity, the depreciation of the dollar and increases in foreign income were the most significant factors. To quantify the relative importance of the various factors, we calculate their contributions to aggregate export growth in the next section.

\section{Contributions to Aggregate Export Growth}

To assess the contributions of changes in exchange rates, foreign demand and domestic productivity to aggregate export growth, we assess the role of the three variables in export growth at each plant and then aggregate back up to determine the overall impact.

To start we make use of the decomposition reported in Equation 1,

$$
\Delta E=\underbrace{\sum_{i} \Delta S_{i} \overline{\left(E_{i} / S_{i}\right)}}_{\text {Growth Effect }}+\underbrace{\sum_{i} \Delta\left(E_{i} / S_{i}\right) \overline{S_{i}}}_{\text {Intensity Effect }} .
$$

The contribution of each plant to the aggregate increase in exports is given by the sum of the growth and intensity effects, i.e. the change in plant exports due to increased output with a constant export-shipments ratio and the change in plant exports due to increasing export intensity.

For the sample of all plants, we regress each of these components of plant export growth on our three explanatory variables and report the results in Table 8.

$$
\begin{aligned}
& \Delta \text { Growth Effect }_{i j}=\delta_{1} \Delta X R_{j}+\delta_{2} \Delta \ln Y_{j}+\delta_{3} \Delta \ln \left(\frac{V A}{N}\right)_{i j}+\epsilon_{i j} . \\
& \Delta \text { Intensity Effect }_{i j}=\delta_{4} \Delta X R_{j}+\delta_{5} \Delta \ln Y_{j}+\delta_{6} \Delta \ln \left(\frac{V A}{N}\right)_{i j}+\epsilon_{i j} .
\end{aligned}
$$

For the intensity effect, all the variables have the expected signs and are significant, confirming the results from the previous regressions. Once again the magnitude of the foreign variables is substantially larger than for the 
productivity measure. Interestingly, for the growth effect regression, only the foreign demand and productivity changes are significant. The exchange measure is insignificant with the wrong sign.

To compute the contributions of the three variables to aggregate exports, we rerun the regressions for five quintiles of plants, ranked according to their employment size in 1987, and compute the contribution of the intensity and growth effects for each quintile to the aggregate increase in exports

$$
\begin{aligned}
\widehat{\Delta E}= & \sum_{q} \sum_{i \in q}\left(\delta_{1} \Delta X R_{j}+\delta_{2} \Delta \ln Y_{j}+\delta_{3} \Delta \ln \left(\frac{V A}{N}\right)_{i j}\right) \\
& +\sum_{q} \sum_{i \in q}\left(\delta_{4} \Delta X R_{j}+\delta_{5} \Delta \ln Y_{j}+\delta_{6} \Delta \ln \left(\frac{V A}{N}\right)_{i j}\right)
\end{aligned}
$$

The results are reported in Table 9, with the actual change in exports by quintile in the upper part of the table and the estimated exchange rate, foreign income and productivity contributions by quintile in the lower panel. As expected, the largest quintile of plants is by far the most important in terms of export quantities accounting for well over $80 \%$ of the total change in exports. Also, as reported earlier, the intensity effect accounts for almost two thirds of the aggregate export increase.

For the estimated changes, we can now assess the relative contribution of exchange rate, foreign income and productivity changes to the growth and intensity effects. The largest plants again dominate the aggregate but looking across the size groups we find relatively little variation in the relative contribution of the three explanatory factors.

For the growth effect, the dominant component is foreign demand with productivity changes contributing about one quarter of the total. The exchange rate contribution is actually negative (remember the insignificant coefficient with the incorrect sign) but even adding the effects from the two foreign variables they still account for the bulk of the export increase.

The results for the intensity component are even stronger. The two foreign measures now make up over $97 \%$ of the total. In aggregate, changes in the exchange rates and especially foreign income account for over $90 \%$ of the change in exports. Productivity improvements do show up as significant but play a much more minor role in the overall export boom. 


\section{Conclusions}

In this paper, we attempt to discriminate between competing explanations for the U.S. export boom after 1987. We consider two hypotheses, one which posits that the export boom was a response to favorable exchange rate and demand changes and another which argues that improved productivity in U.S. firms was the source of the increased exports.

We start by placing the export boom in a broader historical context. While export growth rates were somewhat above average after 1987, the value of real exports appears to have merely returned to long run trend levels. The truly unusual component of the recent export experience has been the unprecedented increase in export intensity at all levels of the economy. Both individual firms and industries are shipping greater fractions of their goods abroad than at any previous time.

We use comprehensive plant-level data to investigate the source of both the rapid growth in exports and the increased intensity. Improvements in exchange rates (real depreciation) and foreign income are strongly associated with both increases in quantities of exports and especially increased export intensity. On the other hand, while productivity increases are indeed associated with increased exports at the plant level, they are not systematically related to increased export intensity. Finally we present an attempt to quantify the importance of the various factors and find that, in aggregate, productivity gains from 1987-1992 accounted for under 10\% of overall export growth. Foreign income growth and exchange rate changes were the dominant sources of the export boom.

These results have both positive and cautionary implications for predictions about export growth in the near future. On the positive side, to the extent that foreign income is the most important determinant of export growth and does not slow dramatically, we should expect to see export growth rates similar to the long run average of about $6 \%$ per year. On a more cautionary note, the large depreciation of the mid 1980s has most probably run its course. This means that the $8 \%$ average growth of recent years is less likely to be repeated. In addition, slower income growth of U.S. trading partners and a large appreciation of the dollar are likely to lead to substantially slower export growth rates. Finally, this paper provides evidence that the rapid export growth, while associated with gains in firm productivity, is more a return to a long run trend than evidence of improved manufacturing 
competitiveness. 


\section{References}

Baldwin, Robert. (1988) "Hysteresis in Import Prices: The Beachhead Effect." American Economic Review, 78(4) pp.773-785.

Baldwin, Robert and Paul Krugman. (1989) "Persistent Effects of Large Exchange Rate Shocks." Quarterly Journal of Economics, Vol. 104, No. 4 pp. 635-654.

Bernard, Andrew B. and J. Bradford Jensen. (1995). "Exporters, Jobs, and Wages in U.S. Manufacturing, 1976-1987." Brookings Papers on Economic Activity, Microeconomics. Washington DC.

Bernard, Andrew B. and J. Bradford Jensen. (1997). "Why Some Firms Export". Yale mimeo.

Bernard, Andrew B. and J. Bradford Jensen. (1998). "Exceptional Exporter Performance: Cause, Effect, or Both?" Journal of International Economics, forthcoming.

Davis, Steven, John Haltiwanger, and Scott Schuh. (1996) Gross Job Creation and Destruction.

Dixit, Avinash. (1989) "Hysteresis, Import Penetration, and Exchange Rate Pass-Through." Quarterly Journal of Economics, Vol. 104, No. 2 pp. 205-228.

Krugman, Paul. (1989) Exchange Rate Instability. MIT Press, Cambridge MA.

U.S. Bureau of the Census. (1987). Census of Manufactures General Summary MC87-S-1. Department of Commerce. 
Figure 1

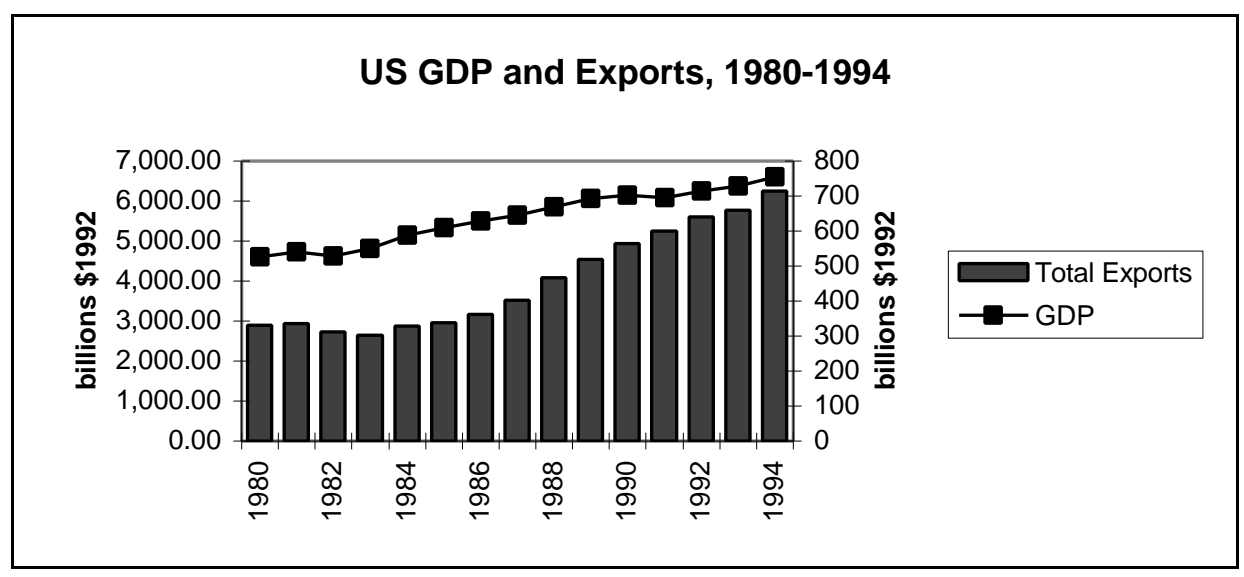

Source: Economic Report of The President, 1996 
Table 1: Shipments and Direct Exports by Industry: 1987, 1992 ${ }^{1}$ (Plants with >20 employees)

\begin{tabular}{|c|c|c|c|c|c|c|c|c|c|c|c|c|}
\hline \multirow[b]{3}{*}{ Industry } & \multicolumn{6}{|c|}{ Shipments } & \multicolumn{6}{|c|}{ Direct Exports } \\
\hline & \multicolumn{2}{|l|}{1987} & \multicolumn{2}{|l|}{1992} & \multicolumn{2}{|c|}{ Growth } & \multicolumn{2}{|c|}{1987} & \multicolumn{3}{|c|}{1992} & Srowth \\
\hline & $\begin{array}{c}\text { Value } \\
\text { (\$Millions) }\end{array}$ & Rank & $\begin{array}{c}\text { Value } \\
\text { (\$Millions) }\end{array}$ & Rank & Change & Rank & $\begin{array}{c}\text { Value } \\
\text { (\$Millions) }\end{array}$ & Rank & $\begin{array}{c}\text { Value } \\
\text { (\$Millions) }\end{array}$ & Rank & Change & Rank \\
\hline Food & 308,516 & 2 & 380,136 & 2 & $21 \%$ & 6 & 5,790 & 6 & 12,457 & 6 & $77 \%$ & 8 \\
\hline Tobacco & 20,715 & 19 & 34,793 & 18 & $52 \%$ & 1 & 1,804 & 11 & 4,362 & 211 & $88 \%$ & $b$ \\
\hline Textiles & 59,752 & 13 & 67,798 & 13 & $13 \%$ & 14 & 805 & 16 & 1,907 & $7 \quad 16$ & $86 \%$ & 6 \\
\hline Apparel & 54,510 & 15 & 59,275 & 15 & $8 \%$ & 18 & 422 & 18 & 1,129 & 18 & $98 \%$ & $b$ \\
\hline Wood & 56,645 & 14 & 63,358 & 14 & $11 \%$ & 16 & 1,759 & 12 & 2,959 & 12 & $52 \%$ & 15 \\
\hline Furnitu & 34,426 & 17 & 38,913 & 17 & $12 \%$ & 15 & 220 & 20 & 938 & 319 & $145 \%$ & 6 \\
\hline Paper & 106,724 & 9 & 129,301 & 9 & $19 \%$ & 7 & 4,633 & 7 & 7,695 & 8 & $51 \%$ & 16 \\
\hline Printing & 98,937 & 11 & 118,224 & 11 & $18 \%$ & 9 & 482 & 17 & 1,523 & 317 & $115 \%$ & 6 \\
\hline Chemicals & 210,670 & 3 & 280,765 & 3 & $29 \%$ & 2 & 17,320 & 3 & 27,278 & 3 & $45 \%$ & 18 \\
\hline Petroleum & 121,298 & 7 & 139,140 & 7 & $14 \%$ & 12 & 1,390 & 13 & 2,588 & 313 & $62 \%$ & 10 \\
\hline Rubber & 80,981 & 12 & 105,021 & 12 & $26 \%$ & 3 & 2,410 & 10 & 4,919 & 10 & $71 \%$ & 9 \\
\hline Leather & 8,520 & 20 & 8,442 & 20 & $-1 \%$ & 19 & 373 & 19 & 582 & 20 & $45 \%$ & 19 \\
\hline Stone & 52,765 & 16 & 52,023 & 16 & $-1 \%$ & 20 & 1,388 & 14 & 2,376 & $5 \quad 14$ & $54 \%$ & 14 \\
\hline Primar & 115,173 & 8 & 131,203 & 8 & $13 \%$ & 13 & 2,668 & 9 & 6,126 & 9 & $83 \%$ & 6 \\
\hline $\begin{array}{l}\text { Fabricated } \\
\text { Metals }\end{array}$ & 130,871 & 6 & 146,030 & 6 & $11 \%$ & 17 & 4,474 & 8 & 8,045 & 7 & $59 \%$ & 13 \\
\hline Machinery & 198,662 & 4 & 228,064 & 4 & $14 \%$ & 11 & 19,527 & 2 & 36,098 & 2 & $61 \%$ & 11 \\
\hline Electronics & 164,070 & 5 & 206,887 & 5 & $23 \%$ & 4 & 11,922 & 4 & 21,661 & 4 & $60 \%$ & 12 \\
\hline Transportation & 326,723 & 1 & 383,158 & 1 & $16 \%$ & 10 & 34,377 & 1 & 52,639 & 1 & $43 \%$ & 20 \\
\hline Instru & 103,326 & 10 & 127,467 & 10 & $21 \%$ & 5 & 11,400 & 5 & 18,109 & 5 & $46 \%$ & 17 \\
\hline Miscellaneous & 26,918 & 18 & 32,363 & 19 & $18 \%$ & 8 & 854 & 15 & 1,926 & $5 \quad 15$ & $81 \%$ & $b$ \\
\hline Total & $2,280,201$ & & $2,732,362$ & & $18 \%$ & & 124,01 & & 215,31 & & $55 \%$ & \\
\hline & & & & & & & ר & & 0 & & & \\
\hline
\end{tabular}

Source: Census of Manufactures, 1987 and 1992. Growth is calculated as the difference in natural logs.

\footnotetext{
${ }^{1}$ As mentioned above, direct exports systematically undercount total industry exports and are reported here to indicate the relative magnitude of the changes that took place during the period.
} 
Table 2: Export Participation by Industry - 1987 and 1992

\begin{tabular}{|c|c|c|c|c|c|c|}
\hline \multicolumn{7}{|c|}{$\begin{array}{c}\text { Share of Plants that Export by Industry, } \\
\text { Industry Share of Total Output and Exports } \\
1987 \text { and } 1992^{2}\end{array}$} \\
\hline \multirow[b]{2}{*}{ Industry } & \multicolumn{3}{|c|}{1987} & \multicolumn{3}{|c|}{1992} \\
\hline & $\begin{array}{l}\text { \% Plants } \\
\text { Exporters }\end{array}$ & $\begin{array}{l}\text { Industry } \\
\text { Share of All } \\
\text { Shipments }\end{array}$ & $\begin{array}{l}\text { Industry } \\
\text { Share of All } \\
\text { Exports }\end{array}$ & $\begin{array}{l}\text { \% Plants } \\
\text { Exporters }\end{array}$ & $\begin{array}{l}\text { Industry } \\
\text { Share of All } \\
\text { Shipments }\end{array}$ & $\begin{array}{l}\text { Industry } \\
\text { Share of All } \\
\text { Exports }\end{array}$ \\
\hline All & .210 & 1.00 & 1.00 & .302 & 1.00 & 1.00 \\
\hline Food & .152 & .135 & .047 & .228 & .139 & .058 \\
\hline Tobacco & .451 & .009 & .015 & .513 & .013 & .020 \\
\hline Textiles & .160 & .026 & .006 & .249 & .025 & .009 \\
\hline Apparel & .045 & .024 & .003 & .094 & .022 & .005 \\
\hline Wood & .115 & .025 & .014 & .176 & .024 & .014 \\
\hline Furniture & .101 & .015 & .002 & .247 & .014 & .004 \\
\hline Paper & .191 & .047 & .037 & .305 & .047 & .035 \\
\hline Printing & .048 & .044 & .004 & .099 & .044 & .007 \\
\hline Chemicals & .400 & .094 & .141 & .490 & .104 & .127 \\
\hline Petroleum & .220 & .053 & .011 & .300 & .050 & .012 \\
\hline Rubber & .257 & .035 & .019 & .364 & .038 & .023 \\
\hline Leather & .186 & .004 & .003 & .282 & .003 & .003 \\
\hline Stone, Clay & .143 & .023 & .011 & .208 & .019 & .011 \\
\hline Pri. Metal & .271 & .050 & .021 & .387 & .047 & .028 \\
\hline Fab. Metal & .210 & .058 & .036 & .314 & .055 & .040 \\
\hline Machinery & .330 & .087 & .157 & .431 & .085 & .172 \\
\hline Electr. Eq. & .374 & .072 & .096 & .463 & .075 & .098 \\
\hline Transport. & .291 & .142 & .276 & .398 & .138 & .243 \\
\hline $\begin{array}{l}\text { Instrument } \\
\mathrm{S}\end{array}$ & .479 & .045 & .092 & .549 & .046 & .081 \\
\hline Misc. Mfg. & .197 & .012 & .007 & .341 & .012 & .009 \\
\hline
\end{tabular}

\footnotetext{
${ }^{2}$ Plants with fewer than 20 employees are excluded from this analysis.
} 
Table 3: Shipments and Direct Exports By State $(1987,1992)$

(Plants with >20 employees)

\begin{tabular}{|c|c|c|c|c|c|c|c|c|c|c|c|c|}
\hline \multirow[b]{3}{*}{ State } & \multicolumn{6}{|c|}{ Shipments } & \multicolumn{6}{|c|}{ Direct Exports } \\
\hline & \multicolumn{2}{|c|}{1987} & \multicolumn{2}{|c|}{1992} & \multicolumn{2}{|c|}{ Growth } & \multicolumn{2}{|c|}{1987} & \multicolumn{2}{|c|}{1992} & \multicolumn{2}{|c|}{ Growth } \\
\hline & \$mil. & Rank & \$mil. & Rank & Change & Rank & \$mil. & Rank & \$mil. & Rank & Change & Rank \\
\hline Maine & 9,909 & 39 & 10,516 & 38 & $6 \%$ & 44 & 520 & 36 & 852 & 39 & $49 \%$ & 31 \\
\hline New Hampshire & 11,374 & 35 & 10,183 & 39 & $-11 \%$ & 48 & 684 & 34 & 979 & 37 & $36 \%$ & 40 \\
\hline Vermont & 4,289 & 42 & 5,791 & 43 & $30 \%$ & 10 & 329 & 42 & 428 & 43 & $26 \%$ & 42 \\
\hline Massachusetts & 57,162 & 13 & 58,016 & 18 & $1 \%$ & 47 & 3,730 & 10 & 5,711 & 12 & $43 \%$ & 35 \\
\hline Rhode Island & 11,062 & 36 & 8,323 & 41 & $-28 \%$ & 49 & 411 & 39 & 468 & 42 & $13 \%$ & 45 \\
\hline Connecticut & 34,472 & 24 & 36,970 & 25 & $7 \%$ & 43 & 3,229 & 14 & 4,693 & 15 & $37 \%$ & 39 \\
\hline New York & 121,910 & 6 & 124,896 & 7 & $2 \%$ & 46 & 7,022 & 6 & 10,778 & 6 & $43 \%$ & 34 \\
\hline New Jersey & 75,139 & 10 & 77,032 & 12 & $2 \%$ & 45 & 2,224 & 20 & 3,920 & 20 & $57 \%$ & 27 \\
\hline Pennsylvania & 109,910 & 7 & 127,586 & 6 & $15 \%$ & 37 & 3,890 & 9 & 7,221 & 9 & $62 \%$ & 23 \\
\hline Ohio & 149,161 & 3 & 172,504 & 3 & $15 \%$ & 38 & 9,268 & 3 & 13,816 & 3 & $40 \%$ & 38 \\
\hline Indiana & 80,362 & 9 & 99,120 & 9 & $21 \%$ & 26 & 3,253 & 13 & 5,890 & 10 & $59 \%$ & 25 \\
\hline Illinois & 122,345 & 5 & 145,411 & 5 & $17 \%$ & 35 & 5,276 & 7 & 8,811 & 7 & $51 \%$ & 30 \\
\hline Michigan & 139,645 & 4 & 150,416 & 4 & $7 \%$ & 41 & 9,653 & 2 & 11,417 & 5 & $17 \%$ & 44 \\
\hline Wisconsin & 65,355 & 12 & 81,930 & 11 & $23 \%$ & 23 & 2,630 & 15 & 5,879 & 11 & $80 \%$ & 12 \\
\hline Minnesota & 44,622 & 19 & 52,617 & 21 & $16 \%$ & 36 & 2,623 & 16 & 2,935 & 23 & $11 \%$ & 46 \\
\hline Iowa & 32,948 & 25 & 43,579 & 24 & $28 \%$ & 12 & 1,597 & 24 & 2,730 & 25 & $54 \%$ & 28 \\
\hline Missouri & 55,781 & 14 & 68,734 & 14 & $21 \%$ & 28 & 3,908 & 8 & 4,257 & 17 & $9 \%$ & 48 \\
\hline North Dakota & 2,328 & 46 & 3,361 & 46 & $37 \%$ & 7 & 147 & 44 & 323 & 44 & $79 \%$ & 13 \\
\hline South Dakota & 3,572 & 44 & 5,627 & 44 & $45 \%$ & 2 & 132 & 45 & 146 & 47 & $10 \%$ & 47 \\
\hline Nebraska & 14,438 & 34 & 20,743 & 34 & $36 \%$ & 8 & 456 & 38 & 1,390 & 34 & $112 \%$ & 2 \\
\hline Kansas & 28,329 & 26 & 33,712 & 26 & $17 \%$ & 34 & 1,140 & 29 & 2,251 & 28 & $68 \%$ & 18 \\
\hline Delaware & 10,341 & 38 & 12,378 & 36 & $18 \%$ & 31 & 347 & 41 & 853 & 38 & $90 \%$ & 6 \\
\hline Maryland & 25,856 & 27 & 28,407 & 29 & $9 \%$ & 40 & 1,435 & 25 & 2,167 & 29 & $41 \%$ & 37 \\
\hline Virginia & 49,129 & 17 & 61,710 & 16 & $23 \%$ & 22 & 2,471 & 17 & 4,647 & 16 & $63 \%$ & 20 \\
\hline West Virginia & 10,544 & 37 & 11,987 & 37 & $13 \%$ & 39 & 763 & 32 & 800 & 40 & $5 \%$ & 49 \\
\hline North Carolina & 91,368 & 8 & 118,399 & 8 & $26 \%$ & 16 & 3,490 & 11 & 8,316 & 8 & $87 \%$ & 8 \\
\hline South Carolina & 38,236 & 23 & 47,115 & 23 & $21 \%$ & 27 & 1,923 & 22 & 4,086 & 18 & $75 \%$ & 16 \\
\hline Georgia & 71,444 & 11 & 85,159 & 10 & $18 \%$ & 32 & 2,241 & 19 & 5,207 & 14 & $84 \%$ & 10 \\
\hline Florida & 50,601 & 16 & 54,356 & 19 & $7 \%$ & 42 & 3,294 & 12 & 5,282 & 13 & $47 \%$ & 32 \\
\hline Kentucky & 39,307 & 21 & 53,117 & 20 & $30 \%$ & 9 & 1,783 & 23 & 3,290 & 22 & $61 \%$ & 24 \\
\hline Tennessee & 53,988 & 15 & 71,006 & 13 & $27 \%$ & 13 & 1,985 & 21 & 4,008 & 19 & $70 \%$ & 17 \\
\hline Alabama & 38,436 & 22 & 49,195 & 22 & $25 \%$ & 18 & 1,175 & 28 & 2,840 & 24 & $88 \%$ & 7 \\
\hline Mississippi & 23,129 & 29 & 30,394 & 28 & $27 \%$ & 14 & 1,014 & 30 & 1,822 & 32 & $59 \%$ & 26 \\
\hline Arkansas & 23,694 & 28 & 31,585 & 27 & $29 \%$ & 11 & 678 & 35 & 1,894 & 31 & $103 \%$ & 3 \\
\hline Louisiana & 46,150 & 18 & 58,102 & 17 & $23 \%$ & 21 & 2,270 & 18 & 3,485 & 21 & $43 \%$ & 33 \\
\hline Oklahoma & 22,477 & 30 & 28,070 & 31 & $22 \%$ & 25 & 709 & 33 & 1,377 & 35 & $66 \%$ & 19 \\
\hline Texas & 149,716 & 2 & 192,358 & 2 & $25 \%$ & 17 & 8,912 & 4 & 13,489 & 4 & $41 \%$ & 36 \\
\hline Montana & 2,775 & 45 & 3,394 & 45 & $20 \%$ & 30 & 57 & 48 & 75 & 48 & $28 \%$ & 41 \\
\hline Idaho & 6,291 & 41 & 9,250 & 40 & $39 \%$ & 6 & 409 & 40 & 1,627 & 33 & $138 \%$ & 1 \\
\hline Wyoming & 1,657 & 49 & 2,161 & 49 & $27 \%$ & 15 & 10 & 49 & 13 & 49 & $25 \%$ & 43 \\
\hline Colorado & 21,336 & 32 & 26,955 & 32 & $23 \%$ & 19 & 945 & 31 & 2,011 & 30 & $76 \%$ & 15 \\
\hline New Mexico & 3,579 & 43 & 8,264 & 42 & $84 \%$ & 1 & 76 & 47 & 178 & 45 & $84 \%$ & 9 \\
\hline Arizona & 18,940 & 33 & 23,317 & 33 & $21 \%$ & 29 & 1,263 & 26 & 2,357 & 27 & $62 \%$ & 22 \\
\hline Utah & 9,418 & 40 & 14,388 & 35 & $42 \%$ & 4 & 288 & 43 & 735 & 41 & $94 \%$ & 5 \\
\hline Nevada & 2,098 & 48 & 2,646 & 48 & $23 \%$ & 20 & 86 & 46 & 161 & 46 & $63 \%$ & 21 \\
\hline Washington & 42,091 & 20 & 65,131 & 15 & $44 \%$ & 3 & 8,430 & 5 & 21,886 & 2 & $95 \%$ & 4 \\
\hline Oregon & 22,439 & 31 & 28,117 & 30 & $23 \%$ & 24 & 1,226 & 27 & 2,665 & 26 & $78 \%$ & 14 \\
\hline California & 227,342 & 1 & 270,836 & 1 & $18 \%$ & 33 & 14,111 & 1 & 23,822 & 1 & $52 \%$ & 29 \\
\hline Alaska & 2,250 & 47 & 3,339 & 47 & $40 \%$ & 5 & 509 & 37 & 1,171 & 36 & $83 \%$ & 11 \\
\hline
\end{tabular}


Figure 2

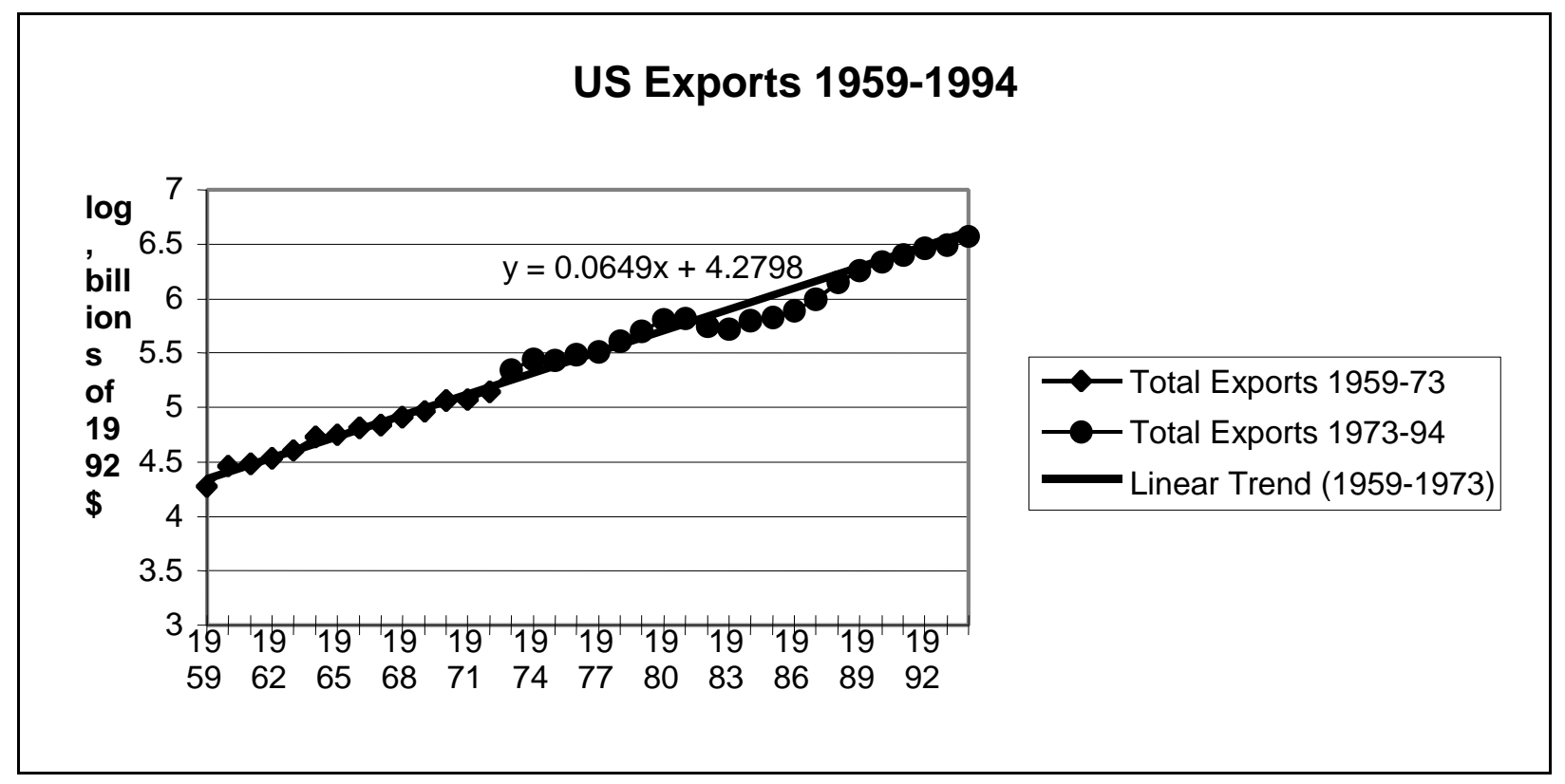

Source: Economic Report of The President, 1996 
Figure 3

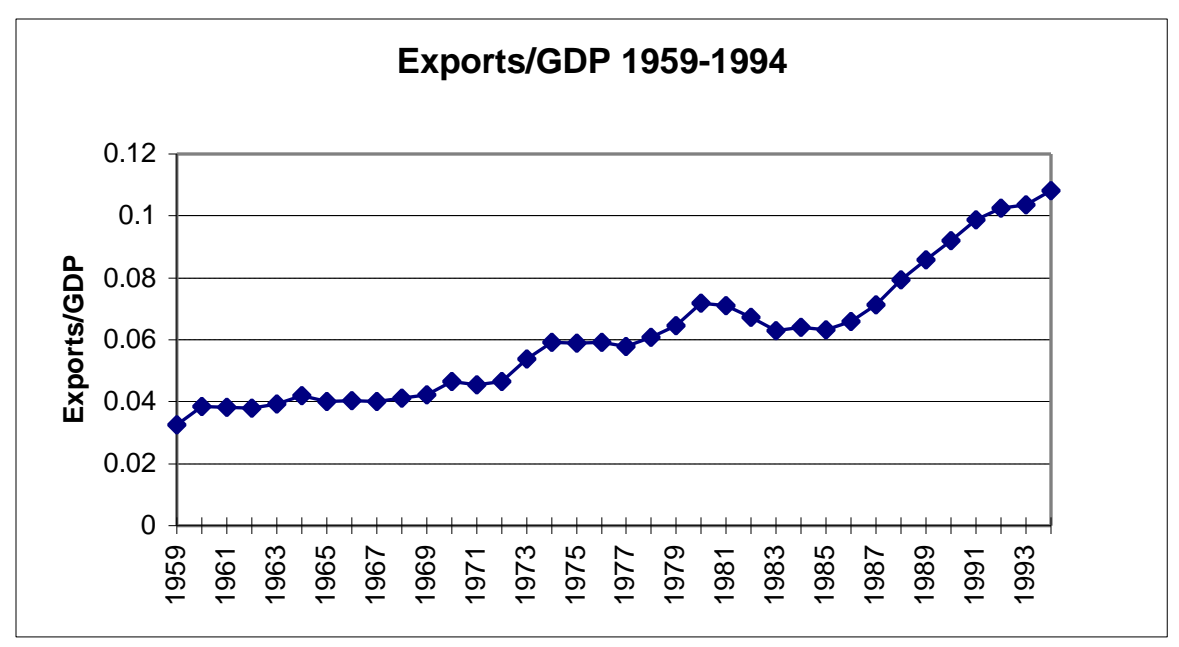

Source: Economic Report of The President, 1996 


\section{Table 4 : Exports by Plant Type}

\begin{tabular}{|c|c|c|c|c|c|c|}
\hline \multirow[t]{2}{*}{ Plant type } & \multicolumn{2}{|l|}{ Exports - 1987} & \multicolumn{2}{|c|}{ Exports - 1992} & \multicolumn{2}{|c|}{ Change in Exports } \\
\hline & (\$millions) & $\%$ of total & (\$millions) & $\%$ of total & (\$millions) & $\%$ of total \\
\hline New & $\$ 0$ & $0 \%$ & $\$ 23,392$ & $11 \%$ & $\$ 23,392$ & $29 \%$ \\
\hline Failed & $\$ 13,241$ & $11 \%$ & $\$ 0$ & $0 \%$ & $(\$ 13,241)$ & $-16 \%$ \\
\hline Continuing & $\$ 111,941$ & $89 \%$ & $\$ 182,693$ & $89 \%$ & $\$ 70,751$ & $87 \%$ \\
\hline Stoppers & $\$ 9,723$ & $8 \%$ & $\$ 0$ & $0 \%$ & $(\$ 9,723)$ & $-12 \%$ \\
\hline Starters & $\$ 0$ & $0 \%$ & $\$ 30,801$ & $15 \%$ & $\$ 30,801$ & $38 \%$ \\
\hline Both & $\$ 102,218$ & $82 \%$ & $\$ 151,891$ & $74 \%$ & $\$ 49,673$ & $61 \%$ \\
\hline All & $\$ 125,183$ & & $\$ 206,085$ & & $\$ 80,901$ & \\
\hline
\end{tabular}


Figure 4

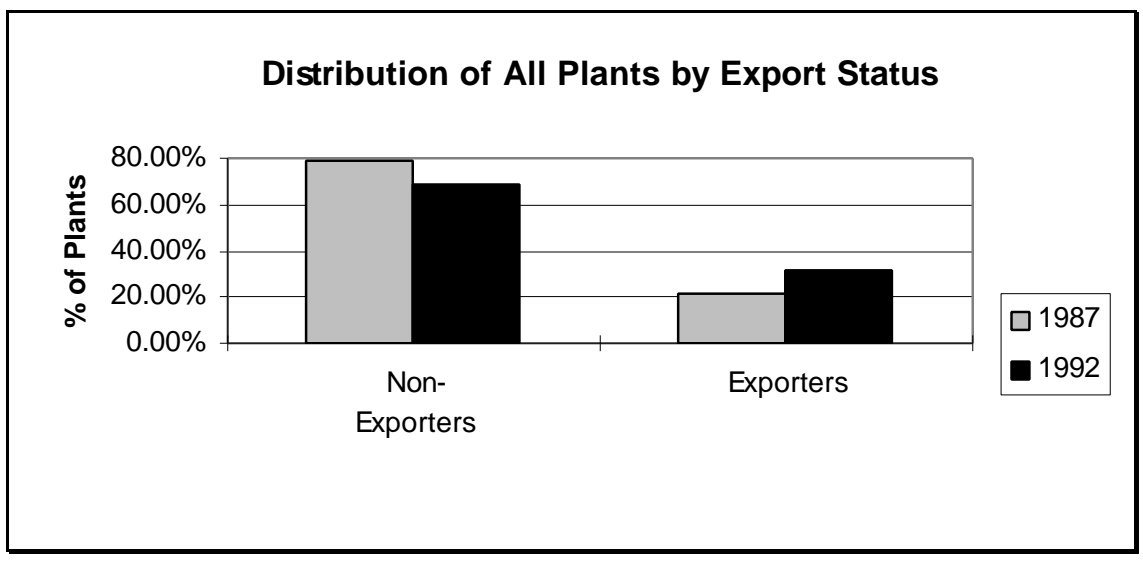


Figure 5

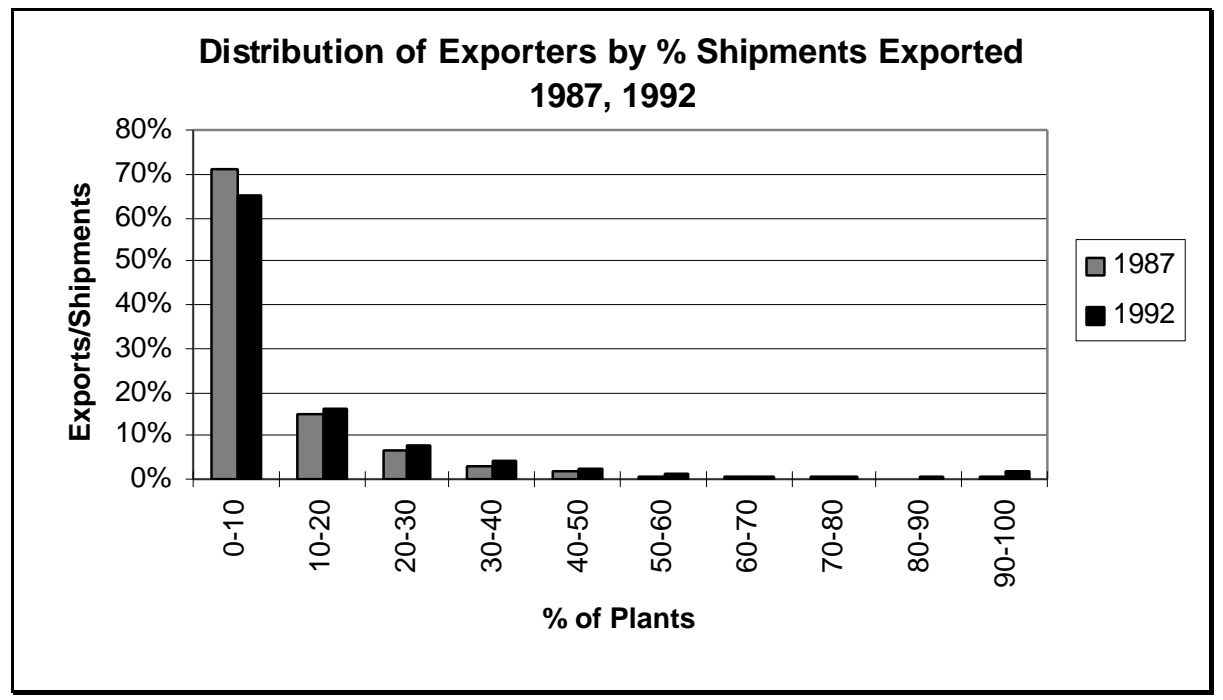


Table 5 : Decomposition of Export Growth (1987-1992)

\begin{tabular}{|c|c|c|c|c|c|c|}
\hline Exporter Type & $\begin{array}{l}\text { Growth Effect } \\
\text { Change in Shipments } \\
* \text { Average Export } \\
\text { Intensity } \\
\text { (\$millions) }\end{array}$ & & $\begin{array}{c}\text { Intensity Effect } \\
\text { Change in Export } \\
\text { Intensity* Average } \\
\text { Shipments } \\
\text { (\$millions) }\end{array}$ & & tillions) & \\
\hline Stoppers & 139 & $0 \%$ & $-9,861$ & $-14 \%$ & $-9,722$ & $-14 \%$ \\
\hline Starters & 4,149 & $6 \%$ & 26,652 & $38 \%$ & 30,801 & $44 \%$ \\
\hline Both & 21,547 & $30 \%$ & 28,125 & $40 \%$ & 49,673 & $70 \%$ \\
\hline All Continuing & 25,836 & $37 \%$ & 44,916 & $63 \%$ & 70,752 & $100 \%$ \\
\hline
\end{tabular}


Figure 6

Supply Shift

(Productivity Increase)

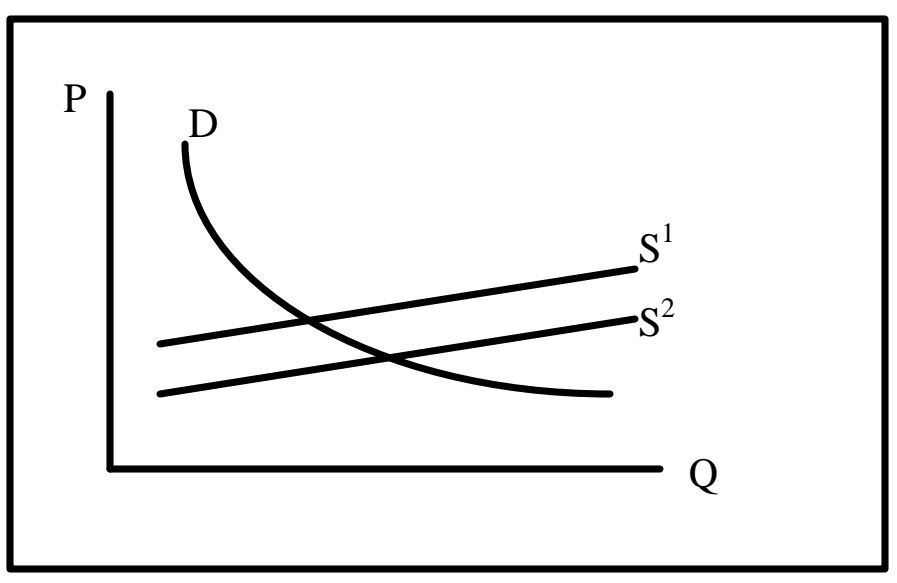

Demand Shift

(Exchange Rate, Foreign Income)

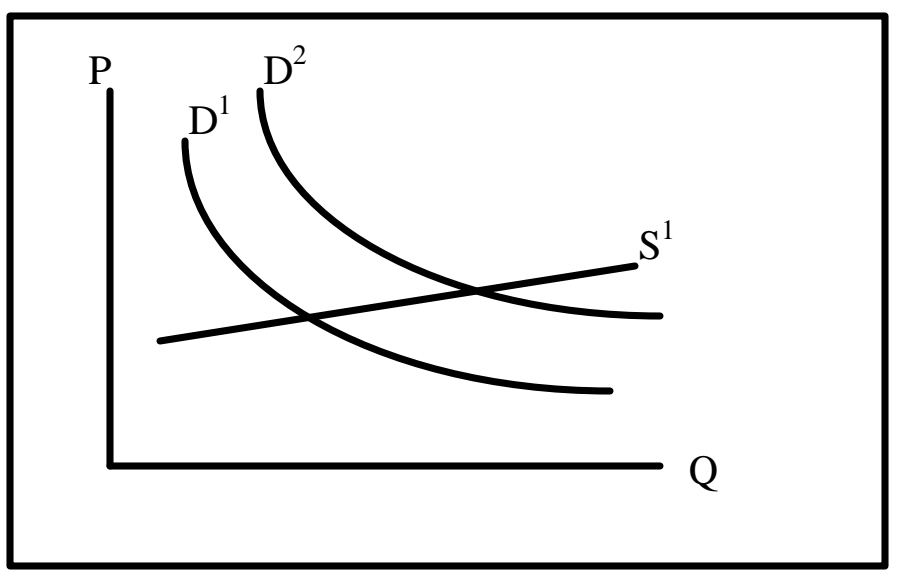


Table 6 : Changes in Exports, Exports/Shipments 1987-1992

(All Plants)

Dependent

Variable

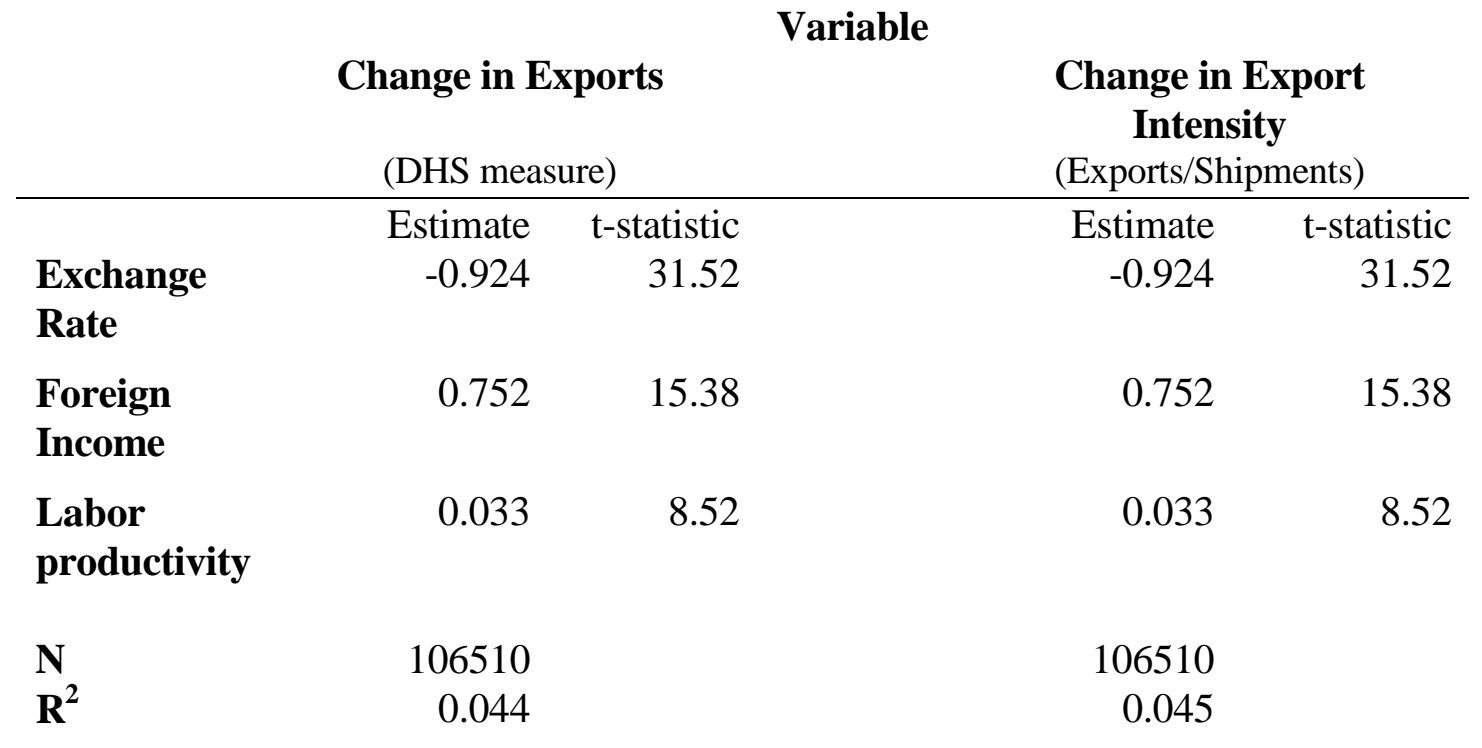


Table 7 : Changes in Exports, Exports/Shipments 1992-1987

\section{Continuing Exporters}

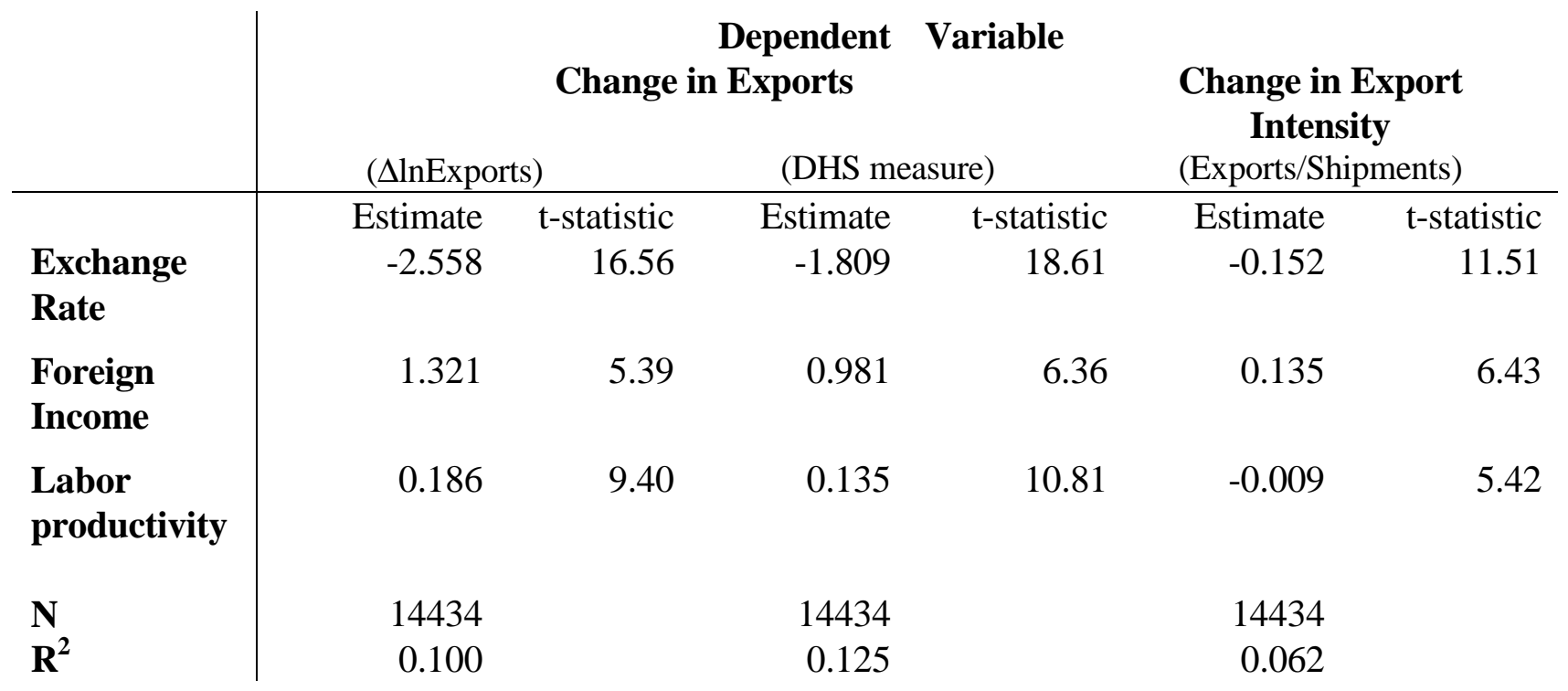


Table 8 : Changes in Exports - Decomposition

All Plants, 1992-1987

\begin{tabular}{l|rrrr} 
& \multicolumn{4}{|c}{$\begin{array}{l}\text { Dependent } \\
\text { Variable }\end{array}$} \\
& Growth Effect & & Intensity Effect \\
\hline $\begin{array}{l}\text { Exchange } \\
\text { Rate }\end{array}$ & Estimate & t-statistic & Estimate & t-statistic \\
$\begin{array}{l}\text { Foreign } \\
\text { Income }\end{array}$ & 286.2 & 0.49 & -1109.5 & 3.38 \\
Labor & & & & \\
productivity & 3414.8 & 3.48 & 2773.4 & 5.07 \\
& & & & \\
$\mathbf{N}$ & 676.5 & 8.62 & 130.7 & 2.99 \\
$\mathbf{R}^{2}$ & & & & \\
& 106497 & & 106497 & \\
& 0.001 & & 0.002 &
\end{tabular}


Table 9 : Contributions of Foreign Income, Exchange Rates and Productivity to Export Growth

\begin{tabular}{|c|c|c|c|c|c|c|c|c|}
\hline \multirow[b]{2}{*}{ Actual } & \multicolumn{5}{|c|}{ Size Groups } & \multirow[b]{2}{*}{$\Sigma$ Quintiles } & \multirow{2}{*}{\multicolumn{2}{|c|}{$\Delta$ in Total Exports }} \\
\hline & $\begin{array}{c}\text { Quintile } \\
1\end{array}$ & $\begin{array}{c}\text { Quintile } \\
2\end{array}$ & $\begin{array}{c}\text { Quintile } \\
3\end{array}$ & $\begin{array}{c}\text { Quintile } \\
4\end{array}$ & $\begin{array}{c}\text { Quintile } \\
5\end{array}$ & & & \\
\hline Growth Effect & $0.7 \%$ & $1.2 \%$ & $2.9 \%$ & $10.1 \%$ & $85.1 \%$ & 25,836 & 70,752 & $36.5 \%$ \\
\hline Intensity Effect & $0.6 \%$ & $1.2 \%$ & $3.5 \%$ & $10.8 \%$ & $83.9 \%$ & 44,916 & & $63.5 \%$ \\
\hline \multicolumn{9}{|l|}{ Estimated } \\
\hline \multicolumn{9}{|l|}{ Growth Effect } \\
\hline Exchange Rate & $-0.9 \%$ & $-1.4 \%$ & $-2.0 \%$ & $-0.6 \%$ & $104.8 \%$ & $(8,492)$ & 60,818 & $-14.0 \%$ \\
\hline Foreign Income & $0.3 \%$ & $0.5 \%$ & $1.4 \%$ & $6.4 \%$ & $91.4 \%$ & 27,265 & & $44.8 \%$ \\
\hline Productivity & $-0.2 \%$ & $0.1 \%$ & $1.1 \%$ & $9.1 \%$ & $89.8 \%$ & 5,317 & & $8.7 \%$ \\
\hline \multicolumn{9}{|l|}{ Intensity Effect } \\
\hline Exchange Rate & $0.0 \%$ & $1.7 \%$ & $4.3 \%$ & $12.8 \%$ & $81.2 \%$ & 11,196 & & $18.4 \%$ \\
\hline Foreign Income & $1.1 \%$ & $1.2 \%$ & $3.0 \%$ & $9.1 \%$ & $85.6 \%$ & 24,746 & & $40.7 \%$ \\
\hline Productivity & $0.3 \%$ & $0.3 \%$ & $2.5 \%$ & $28.2 \%$ & $68.7 \%$ & 783 & & $1.3 \%$ \\
\hline
\end{tabular}

